\title{
Model Pemberdayaan Kelompok Ternak Kelinci melalui Program Pelatihan Pertanian dan Perdesaan Swadaya (studi kasus Kelompok Ternak Kelinci "Mandiri Jaya” di Desa Ngijo, Kecamatan Karangploso, Kabupaten Malang)
}

\section{Empowerment Model of Rabbit Farmer Group in Agriculture Training and Self Supporting System of Rural Program (case study of Mandiri Jaya's Rabbit Farmer Group in Ngijo Village, Karangploso Subdistrict, Malang Regency)}

\author{
Neno Arsya Swastika*, Siti Azizah dan Anie Eka Kusumastuti \\ Bagian Sosial Ekonomi Peternakan, Fakultas Peternakan, Universitas Brawijaya
}

Submitted : 03 August 2017, Accepted : 05 September 2017

\begin{abstract}
ABSTRAK: Tujuan penelitian ini adalah untuk mengetahui bentuk pemberdayaan kelompok ternak kelinci "Mandiri Jaya" melalui Program Pelatihan Pertanian dan Perdesaan Swadaya. Metode yang digunakan dalam penelitian ini yaitu metode survei. Penentuan sampel dalam penelitian kualitatif ini menggunakan bentuk Purposive sampling lalu diteruskan menggunakan Snowball sampling. Hasil dari penelitian ini yaitu bentuk pemberdayaan kelompok ternak kelinci yang diberikan meliputi budidaya kelinci, bina manusia, bina lingkungan dan bina usaha. Bentuk-bentuk pelatihan tersebut diberikan setiap 1 bulan sekali selama 1 tahun (1 periode). Materi budidaya kelinci dimana anggota kelompok diajarkan manajemen kelinci yang baik dan menguntungkan mulai dari pemilihan bibit yang baik, pemberian pakan yang baik serta berkualitas dan sistem perkandangan yang baik untuk kelinci. Materi pembinaan peternak dimaksudkan agar anggota kelompok dapat mengembangkan ide-ide yang ada, bertukar pikiran atau informasi terhadap sesama anggota kelompok ternak serta peranan besar seorang peternak khusunya sebagai peternak kelinci. Materi bina lingkungan diajarkan bagaimana menciptakan lingkungan yang aman dan bersih khususnya berada pada area yang berdekatan dengan kandang ternak. Materi bina usaha dimana anggota kelompok diajarkan bagaimana cara berwirausaha salah satunya lewat hasil olahan ternak kelinci. Saran dari penelitian ini alangkah baiknya diberikan tambahan bentuk pemberdayaan yang lainnya agar anggota kelompok menjadi lebih berkembang lagi.
\end{abstract}

Kata kunci: pemberdayaan, kelompok ternak, program pelatihan.

ABSTRACT: The purpose of this research was to learn the model of empowerment to a rabbit farmer group which is named "Mandiri Jaya" through Agriculture Training and Self Supporting of Rural Program. This research employs survey method. This qualitative research choosed its key informants by using purposive sampling that was followed by Snowball sampling. The result of this research is the model of empowerment that was given to the rabbit farmer group which includes training provided of rabbits, human development, community development, and business development. Various forms of the training are given once in month for annualy. The material training provided includes how to manage the rabbit farmer group, so becomes profitable. For examples how to choose proper and high-quality feed, and to build a good housing system for the rabbit. The material of human development is given so the rabbit farmer group can develop the ideas, exchange their ideas and information with other members. The material of community development is given so that the farmers that are involved know how to build a safe and clean environment especially near the rabbit housing area. The material of business development is given so that the member of the group know how to be a good entrepreneur.

Keywords : empowerment, farmer group, rural program

*Corresponding author: nenoarsya@gmail.com

DOI: 10.21776/ub.jiip.2017.027.03.01 


\section{PENDAHULUAN}

Pemberdayaan masyarakat
merupakan suatu proses dimana
masyarakat yang miskin sumber daya dan
kelompok yang terabaikan lainnya,
didukung agar mampu meningkatkan
kesejahteraannya secara mandiri. Adapun
aspek-aspek yang penting dalam suatu
program pemberdayaan masyarakat yaitu
program yang disusun sendiri oleh
pemerintah, menjawab kebutuhankebutuhan dasar masyarakat, mendukung keterlibatan kaum miskin dan kelompok terabaikan lainnya, dibangun dari sumberdaya lokal, sensitif terhadap nilainilai budaya setempat, memperhatikan dampak lingkungan serta berkelanjutan atau suistanable (Mardikanto, 2013).

Kelompok ternak di pedesaan sudah seharusnya memiliki sumber daya yang cukup untuk memajukan kesejahteraan, sosial dan perekonomian. Namun tidak semuanya memiliki sumber daya yang cukup karena keterbatasan waktu dan kurangnya pelatihan maupun penyuluhan yang diselenggarakan. Kelompok ternak kelinci di Desa Ngijo, Kecamatan Karangploso, Kabupaten Malang merupakan komoditas peternakan unggulan dari Kelompok ternak kelinci "Mandiri Jaya" yang memberdayakan anggotanya melalui pembinaan Program Pelatihan Pertanian dan Perdesaan Swadaya (P4S) dalam menambah pengetahuan dan peningkatan sumber daya manusia. Menurut Departemen Pertanian (2000) bahwa suatu kelompok tani akan digunakan sebagai pendekatan utama dalam suatu kegiatan penyuluhan. Pendekatan kelompok dipandang lebih efisien dan menjadi sebuah media untuk proses belajar mengajar serta berinteraksi dari petani, sehingga diharapkan terjadinya perubahan perilaku petani ke arah yang lebih baik lagi. Kegiatan P4S dilaksanakan setiap 1 (satu) bulan sekali. Program tersebut mulai terlaksana sejak tanggal 25 Februari 2016 hingga bulan Februari 2017 dan diikuti sebanyak 16 peternak yang masih aktif dan berkembang. Pelatihan yang diberikan meliputi budidaya kelinci, bina usaha, bina lingkungan dan bina manusia. Program ini bertujuan untuk pemberdayaan para anggota kelompok ternak sebagai upaya penyediaan kepada anggotaatas su mber, kesempatan, pengetahuan serta ketrampilan untuk meningkatkan kemampuan melalui pelatihan. Menurut Mardikanto (1993), bahwa suatu kegiatan pemberdayaan masyarakat hanya terpusat pada suatu upaya peningkatan produksi dan peningkatan pendapatan serta perbaikan kesejahteraan masyarakat penerima manfaat, namun perhatian terhadap karir fasilitator sebagai pelaksana kegiatan pemberdayaan masyarakat itu sendiri sering dilupakan.

Tujuan dari penelitian ini yaitu mengetahui model pemberdayaan kelompok ternak kelinci melalui kegiatan P4S.

\section{MATERI DAN METODE Waktu dan tempat}

Penelitian dilaksanakan pada tanggal 22 Desember 2016 hingga 20 Februari 2017 di peternakan kelinci "Mandiri Jaya" Jalan Gelatik no. 99 Desa Ngijo, Kecamatan Karangploso, Kabupaten Malang.

\section{Metode penelitian}

Penelitian dilakukan dengan menggunakan metode survei. Data diambil dengan cara wawancara informan menggunakan kuisioner terstrukur. Wawancara (interview) dilakukan secara langsung kepada 16 anggota kelompok ternak dan 1 perwakilan dari pihak instansi terkait.

\section{Metode pengumpulan data}

Pengambilan data dalam penenlitian kualitatif ini pada awalnya menggunakan Purposive Sampling kemudian dilanjutkan dengan Snowball Sampling, yaitu suatu teknik pengambilan sampel sumber data yang pada awalnya memiliki jumlah yang sedikit dan belum mampu untuk memberikan data yang lebih lengkap, maka dari itu harus mencari orang 
lain yang dapat digunakan sebagai sumber data (Sugiyono, 2012).

\section{Analisis data}

Pada penelitian ini menggunakan analisis deskriptif kualitatif karena permasalahan yang dibahas tidak berkenaan dengan angka-angka namun lebih kearah deskripsi, menguraikan dan menggambarkan model pemberdayaan kelompok ternak kelinci yang termasuk didalamnya yaitu budidaya kelinci, bina usaha, bina manusia dan bina lingkungan. Analisis kualitatif berupa proses penyelidikan dalam suatu analisis fenomena yang terjadi dengan cara membandingkan, mengkategorikan, mengklasifikasi, menyajikan serta melaksanakan verifikasi data secara keseluruhan yang bertujuan untuk menemukan keseragaman dan sifat umum obyek yang diteliti (Mubarak, 2010).

\section{HASIL DAN PEMBAHASAN}

Proses pemberdayaan umumnya dilakukan secara kolektif. Adapun model pelatihan yang diberikan dalam kelompok ternak kelinci "Mandiri Jaya" untuk keberdayaan para anggota kelompok melalui P4S, antara lain: a) Budidaya Kelinci; b) Bina Manusia diberikan setiap 1 (satu) bulan sekali selama masa program yang telah ditetapkan.

\section{Budidaya kelinci}

Ternak kelinci merupakan jenis ternak yang mempunyai banyak keunggulan seperti mampu berproduksi dengan cepat dan menghasilkan banyak anak, mudah dan sederhana dalam pemeliharaannya serta tidak memerlukan lahan yang luas. Menurut Wibowo., et al (2008) budidaya kelinci adalah salah satu usaha yang berpeluang besar, karena potensinya yang luar biasa untuk dikembangkan dan prospek untuk kedepannya sangat baik, karena daging kelinci memiliki protein yang tinggi melebihi daging ayam maupun sapi. Menurut Kusnadi dan Bintoro (2012) bahwa kadar protein daging kelinci sebesar $20,8 \%$, protein daging ayam sebesar $20 \%$, protein daging sapi sebesar $16,3 \%$. Selain itu daging kelinci juga rendah akan kalori, kolesterol dan lemak yaitu kadar kalori daging kelinci sebesar 7,3\%, lemak daging kelinci sebesar 10,2\% dan daging kelinci rendah kolesterol mengandung $164 \mathrm{mg}$ per 1000 gram.

Dalam kegiatan P4S salah satu materi pelatihan yang diberikan yaitu budidaya kelinci, anggota kelompok ternak diajarkan bagaimana manajemen kelinci yang baik serta menguntungkan, mulai dari pemilihan bibit yang baik, pemberian pakan berkualitas serta sistem perkandangan yang baik untuk kelinci. Menurut Widodo (2009) pemilihan bibit kelinci yang baik nantinya akan menghasilkan kelinci yang baik pula. Pemilihan bibit kelinci sangat diperlukan dan juga sangat diperhatikan dengan baik, jangan sampai salah dalam memilih bibit sehingga diwaktu merawat terjadi permasalahan. Bibit yang baik harus ditentukan sejak awal sebelum pemeliharaan.

Penerapan budidaya kelinci yang baik dan benar mulai diterapkan oleh seluruh anggota kelompok setelah melihat keuntungan dari budidaya kelinci tersebut yang telah diajarkan pada saat pelatihan. Keuntungan dari berbudidaya kelinci, selain kelinci adalah salah satu ternak yang dapat menambah gizi keluarga, juga rendah akan kalori dan lemak serta mampu meningkatkan pendapatan keluarga seharihari dengan menjualnya ke pasaran karena memiliki prospek yang baik untuk kedepannya. Para anggota kelompok perlahan sudah menerapkan manajemen pemeliharaan yang baik serta menguntungkan. Mereka mampu menghasilkan kelinci pedaging maupun kelinci hias yang berkualitas serta harga jual yang tinggi dipasaran.

Pemeliharaan dengan tekun dan disiplin secara umum menjadi kata kunci yang tidak bisa diabaikan agar usaha budidaya kelinci bisa berhasil dengan baik. Hal tersebut karena berkaitan erat dengan 
berbagai macam faktor seperti faktor kebersihan kandang akan sangat erat kaitanya dengan kesehatan ternak kelinci yang ada di kandang dan faktor pengamatan harian rutin ini berhubungan dengan keadaan kondisi rutin hewan ternak yang ada, kondisinya bagaimana sehat atau tidak semua itu kalau tanpa perlakuan pengamatan yang baik kita tidak akan tahu. Hal tersebut sama halnya dengan pernyataan Darman (2011) bahwa dalam hal perkembangbiakan, kelinci juga membutuhkan perhatian yang terus menerus karena pada saat kelinci dikawinkan sampai masa melahirkan dan sapih anak, penanganan yang dibutuhkan juga harus sesuai fasenya, maka faktor lingkungan/kebersihan kandang berpengaruh terhadap keberhasilannya.

\section{Bina manusia}

Dalam pelatihan materi pembinaan peternak dimaksudkan agar anggota kelompok dapat mengembangkan ide-ide yang ada didalam pikirannya, bertukar pikiran atau informasi terhadap sesama anggota kelompok ternak serta peranan besar seorang peternak khusunya sebagai peternak kelinci untuk mencukupi kebutuhan hidup. Menurut Adi (2016), bahwa bina manusia merupakan suatu usaha yang dilakukan pemerintah melalui partisipasi masyarakat untuk lebih ditingkatkan kembali sehingga mereka mampu memanfaatkan lingkungan yang terbina untuk meningkatkan kualitas kehidupan.

Strategi bina manusia dalam kegiatan P4S yaitu: meningkatkan suatu kreatifitas kelompok; peningkatan kapasitas organisasi; memperluas dan mengeintegrasikan mandat organisasi dan kelompok; memperbaiki budaya kerja yang kerja keras dan tanggung jawab. Kemampuan anggota kelompok harus senantiasa mengikuti suatu perkembangan ilmu, teknologi dan seni yang memiliki manfaat tinggi untuk meningkatkan produktifitas, mutu produk yang lebih tinggi, tingginya efisiensi daya saing produk. Masyarakat harus terus menerus mengembangkan keahlian sesuai kompetensinya, bangga dan mencintai profesinya, serta memegang teguh etika profesinya.

\section{Bina lingkungan}

Setiap pemberian materi tentang pembinaan lingkungan berbeda-beda topik yang diberikan, diantaranya peminimalisiran bau limbah kotoran ternak kelinci (urine, feses), sanitasi kandang dengan penerapan biosecurity yaitu pembersihan kandang kelinci serta penyemprotan dengan menggunakan desinfektan, kondisi rumah yang bersih dan sehat. Menurut Ali (2005), menyatakan bahwa strategi bina lingkungan yaitu: peran masyarakat dalam mengelola dan menata lingkungan hidup lebih ditingkatkan; membangun infrastruktur yang menyangkut kebutuhan masyarakat dalam pelaksanaan kegiatan ekonomi; perencanaan dan pembangunan secara spasial dan daya dukung lingkungannya lebih ditingkatkan; serta kualitas lingkungan hidup melalui konservasi, rehabilitasi, reboisasi dan lain sebagainya lebih ditingkatkan kembali.

Menurut Lidyasanty (2016), bahwa peran masyarakat untuk menciptakan rumah sehat dan bersih dekat dengan kandang yaitu: 1) anggota kelompok menerapkan kontrol sosial; 2) Pemilik ternak harus melindungi diri menggunakan alat pelindung seperti masker, sarung tangan, sepatu boot dan menjauhkan kandang dari jangkauan anak-anak; 3) Peningkatan hygine dan sanitasi individu; 4) Pemeriksaan ternak secara rutin; dan 5) Pemberian pengetahuan kepada anggota kelompok mengenai pemanfaatan kotoran ternak. Pemanfaatan tersebut akan menghasilkan nilai ekonomis yang lebih seperti pemanfaatan media pertumbuhan cacing, pupuk organik, gas bio dan lain sebagainya. 


\section{Bina usaha}

Bina usaha diupayakan melalui pemberdayaan anggota kelompok ternak yaitu diantaranya peningkatan pengetahuan secara teknis, perbaikan mutu dan nilai sebuah produk yang akan dipasarkan serta perbaikan manajemen untuk meningkatkan efisiensi usaha. Dalam kegiatan pelatihan P4S juga diajarkan bagaimana cara berwirausaha dengan baik agar lebih maju, salah satunya lewat hasil olahan ternak kelinci. Kelinci-kelinci peliharaan anggota kelompok mempunyai nilai kualitas yang baik, maka dari itu hasil olahan yang mereka produksi pun juga mempunyai nilai kualitas yang baik juga. Kelinci-kelinci peliharaan mereka dijual dan ada khusus untuk diproduksi diambil hasilnya serta menghasilkan pendapatan yang cukup untuk mencukupi kebutuhan sehari-hari. Anggota kelompok mampu mengaplikasikan atau menerapkan materimateri yang disampaikan dari pelatihan untuk mendapatkan tambahan hasil pendapatan guna mencukupi kebutuhan sehari-hari. Mardikanto (2013), bahwa bina usaha yang diupayakan melalui pemberdayaan masyarakat akan mencakup banyak hal, seperti: peningkatan pengetahuan teknis, utamanya untuk meningkatkan produktivitas, perbaikan mutu dan nilai tambah produk; perbaikan manajemen untuk meningkatkan efisiensi usaha dan pengembangan jejaring kemitraan; pengembangan jiwa kewirausahaan terkait dengan optimasi peluang bisnis yang berbasis dan didukung oleh keunggulan lokal; peningkatan aksesbilitas terhadap modal, pasar dan informasi; advokasi kebijakan yang berpihak kepada ekonomi perkembangan rakyat.

\section{KESIMPULAN}

Model pemberdayaan kelompok ternak kelinci "Mandiri Jaya" diberikan melalui kegiatan P4S yaitu diantaranya: Budidaya kelinci, Bina manusia, Bina Lingkungan dan Bina Usaha. Disimpulkan bahwa dalam pelatihan materi budidaya kelinci anggota kelompok diajarkan bagaimana manajemen pemeliharaan kelinci yang baik dan benar. Bina manusia, dalam materi ini diajarkan bagaimana anggota kelompok dapat mengembangkan ide-ide yang dimilikinya serta pengembangan karakter diri seorang peternak kelinci. Bina lingkungan, dalam materi ini diajarkan bagaimana anggota kelompok dapat menciptakan lingkungan yang bersih dan sehat yang berdekatan dengan kandang. Bina usaha, dalam materi ini anggota kelompok diajarkan bagaimana menghasilkan usaha-usaha berbasis ternak kelinci yang menguntungkan, baik menjual kelinci sebagai kelinci pedaging/hias dan produk-produk berbahan kelinci.

\section{DAFTAR PUSTAKA}

Adi, M. 2016. Manajemen Pembangunan Desa. Pedoman Program Terpadu. Grafindo Utama. Jakarta.

Ali. 2005. Kemitraan dan Model Pemberdayaan Masyarakat. Gava Media: Yogyakarta.

Darman. 2011. Analisis Ekonomi Hasil Ternak kelinci. Fakultas Ekonomi dan Komunikasi. Binus University.

Departemen Kehutanan. 2000. Penyuluhan Pembangunan Kehutanan. Pusat Penyuluhan Kehutanan Departemen Kehutanan bekerjasama dengan Fakultas Pertaninan. Universitas Sebelas Maret Surakarta. Jakarta. http://cybex.deptan.go.id/penyuluhan /pemberdayaan-masyarakat-tanimengarah-pada-kemandirian. Diakses tanggal 22 April 2017.

Kusnadi dan Bintoro. 2012. Daya Ikat Air, Tingkat Kekenyalan dan Kadar Protein pada Bakso Kombinasi Daging Sapi dan Daging Kelinci. Jurnal Aplikasi Teknologi Hasil Pangan. Vol 1(2) : 28-31. 
Lidyasanty, O. 2016. Pengelolaan Limbah

Pencegahan Pencemaran Lingkungan di Kota Kotamobagu. Fakultas Pertanian. Universitas Sam Ratulangi. Manado. Jurnal Zootek. (1) : 226-237.

Mardikanto, T. 1993. Penyuluhan Pembangunan Pertanian. UNS Press: Surakarta.

Mardikanto, T. 2013. Pemberdayaan Masyarakat dalam Perspektif Kebijakan Publik. Alfabeta: Bandung.

Mubarak. 2010. Evaluasi Pemberdayaan Masyarakat ditinjau dari Suatu Proses Pengembangan Kapasitas pada Kegiatan PNPM Mandiri Perkotaan di Desa Sastrodirjan Kabupaten Pekalongan. Fakultas Ilmu Sosial dan Politik. Universitas Diponegoro, Semarang.

Sugiyono. 2012. Metode Penelitian Administrasi. Cetakan ke-20. Alfabeta: Bandung.

Wibowo, B, Sumanto dan Rafif. 2008. Pemanfaatan dan Analisis Ekonomi Usaha Ternak Kelinci di Pedesaan. Lokakarya Nasional Potensi dan Peluang Pengembangan Usaha Kelinci. Balai Penelitian Ternak. Bogor.

Widodo. 2009. Usaha Budidaya Ternak Kelinci dan Potensinya. Jurnal Ilmu Peternakan. 1(1): 26-31. 